\title{
Effect of high temperature on feeding behaviour and heat production in group-housed young pigs
}

\author{
Anne Collin, Jacob van Milgen, Serge Dubois and Jean Noblet* \\ Unité Mixte de Recherches sur le Veau et le Porc, Institut National de la Recherche Agronomique, 35590 Saint-Gilles, \\ France
}

(Received 31 May 2000 - Revised 18 December 2000 - Accepted 11 January 2001)

\begin{abstract}
To assess the acclimation of pigs to heat stress, the effects of high $\left(33^{\circ} \mathrm{C}\right)$ or thermoneutral $\left(23^{\circ} \mathrm{C}\right)$ constant temperatures on feeding behaviour and components of energy balance were studied in group-housed young pigs. Three groups of five pigs were used at each temperature. After 1 week of adaptation, voluntary feed intake (VFI) and heat production (HP) were recorded for thirteen consecutive days. Animals were fed ad libitum. Fasting HP was measured on the last day. Average initial body weights (BW) were 21.4 and $20.9 \mathrm{~kg}$ at 23 and $33^{\circ} \mathrm{C}$ respectively. Feeding behaviour was measured individually and rate of feed intake and characteristics of feeding behaviour were calculated. The $\mathrm{O}_{2}$ consumption, $\mathrm{CO}_{2}$ production and physical activity of the group were used to calculate total $\mathrm{HP}\left(\mathrm{HP}_{\text {tot }}\right)$ and its components, i.e. fasting $\mathrm{HP}\left(\mathrm{HP}_{\text {fas }}\right)$, $\mathrm{HP}$ due to physical activity $\left(\mathrm{HP}_{\mathrm{act}}\right)$ and thermic effect of feed (TEF). The $\mathrm{BW}$ gain and VFI were reduced by 37 and $30 \%$ respectively at $33^{\circ} \mathrm{C}$. The decrease in VFI corresponded to reduced consumption time $(-34 \%)$ and size of the meals $(-32 \%)$. Feeding behaviour was mostly diurnal $(66 \%$ of the VFI), and the rate of feed intake $(28 \mathrm{~g} / \mathrm{min})$ was not affected by temperature. Daily $\mathrm{HP}_{\text {tot }}, \mathrm{HP}_{\text {fas }}$ and $\mathrm{TEF}$, expressed per kg metabolic weight $\left(\mathrm{BW}^{0.60}\right)$, were significantly decreased at $33^{\circ} \mathrm{C}$ by 22,18 and $35 \%$ respectively, whereas $\mathrm{HP}_{\text {act }}$ was not affected; TEF expressed per g feed was not affected $(2 \mathrm{~kJ} / \mathrm{g})$. The decrease in $\mathrm{HP}_{\text {tot }}$ at $33^{\circ} \mathrm{C}$ was caused by a reduction in TEF and $\mathrm{HP}_{\text {fas }}\left(\mathrm{kJ} / \mathrm{d}\right.$ per $\left./ \mathrm{kg} \mathrm{BW}^{0.60}\right)$, which are both related to reduction in VFI.
\end{abstract}

Pig: High temperature: Heat production: Feeding behaviour

Within the thermoneutral zone, dietary energy is used for growth, maintenance and physical activity. Below thermoneutrality, additional energy may need to be diverted from productive processes in order to maintain homeothermy. Under warm conditions, all heat produced has to be evacuated. Pigs exposed to warm environments acclimate by increasing (evaporative) heat loss and by reducing heat production, to maintain body temperature within narrow limits. However, they have a limited capacity to lose heat by water evaporation (Ingram, 1965) and acclimation to warm climatic conditions mainly occurs by reducing heat production (Nienaber \& Hahn, 1982; Quiniou et al. 2001). Reduction in voluntary feed intake (VFI) and the associated thermic effect of feeding (or heat increment; TEF) is an efficient mechanism to reduce heat production (Quiniou et al. 2001). Heat production may also be reduced by a decrease in physical activity or BMR. Although there is information about the effect of temperature on the total heat production $\left(\mathrm{HP}_{\text {tot }}\right)$ in pigs (Nienaber \& Hahn, 1982; Nienaber et al. 1987; Quiniou et al. 2001), little is known about the change in the components of heat production at high temperature. Moreover, these phenomena have been studied mainly in growing pigs and sows. A previous study showed that VFI was at a maximum between 19 and $25^{\circ} \mathrm{C}$ in young pigs weighing about $20 \mathrm{~kg}$, decreased regularly between 25 and $33^{\circ} \mathrm{C}$ and was severely depressed above $33^{\circ} \mathrm{C}$, suggesting that young pigs are heat stressed above $25^{\circ} \mathrm{C}$ (Collin et al. 2001). Based on these results, two temperatures were chosen, representing temperatures within the thermoneutral zone $\left(23^{\circ} \mathrm{C}\right)$ or causing severe heat stress $\left(33^{\circ} \mathrm{C}\right)$. The present study is part of a larger programme in which the effects of high $v$. thermoneutral temperatures are studied in young pigs. The programme includes studies on the physiological (fractional distribution of blood flow) and metabolic and nutritional (mitochondrial metabolism, heat production, feeding

Abbreviations: $\mathrm{BW}$, body weight; $\mathrm{BW}^{0.60}$, metabolic body weight; $\mathrm{HP}_{\mathrm{act}}$, heat production due to physical activity; $\mathrm{HP}_{\text {fas }}$, fasting heat production;

$\mathrm{HP}_{\text {tot }}$, total heat production; TEF, thermic effect of feed; VFI, voluntary feed intake.

* Corresponding author: J. Noblet, fax +332234850 80, email noblet@st-gilles.rennes.inra.fr 
behaviour) consequences of exposure to high temperatures. The present paper focuses on the effects of a high constant temperature on VFI, heat production and its components in 20-30 kg pigs.

\section{Materials and methods}

\section{Animals and husbandry}

Crossbred (Large White $\times$ Landrace $) \times$ Piétrain male pigs, castrated at about $14 \mathrm{~d}$ of age and weaned at $28 \pm 1 \mathrm{~d}$ of age were used for the experiment. After weaning, pigs were reared in groups of twelve animals in a conventional nursery room and offered ad libitum a starter diet providing $213 \mathrm{~g}$ crude protein $(\mathrm{N} \times 6.25) / \mathrm{kg}, 14.0 \mathrm{~g}$ lysine $/ \mathrm{kg}$ and 13.6 MJ metabolisable energy (ME)/kg. At 2 weeks after weaning a group of six pigs of similar body weight (BW) and age, but from different litters, was constituted and placed for adaptation on a $2.3 \times 1.6 \mathrm{~m}$ flat-deck in a room controlled for temperature and relative humidity. The temperature was initially set at $25^{\circ} \mathrm{C}$, and was then progressively decreased or increased within $4 \mathrm{~d}$ to either 23 or $33^{\circ} \mathrm{C}$. At the beginning of the adaptation period, the pigs, BW was $15 \cdot 2$ (SD 1.6) $\mathrm{kg}$ and their age was 46 (SD 1) d. Three groups of pigs were used successively at each temperature.

Rectal temperature and feed intake attain a new constant value within $96 \mathrm{~h}$ after exposure to high temperatures (Rafaï, 1974; Giles, 1992). Consequently, 1 week was considered to be sufficient to adapt the pig to their new environment (at least for the criterion of interest). Five pigs were selected (day 0) from the group on the basis of a similar BW and placed in a pen $(2.3 \times 1.6 \mathrm{~m})$ in a respiration chamber $\left(12 \mathrm{~m}^{3}\right)$ equipped with a metal slatted floor and a slurry pit allowing storage of urine, faeces and water spillage. The slurry pit was emptied on days 6 and 13 . A feed dispenser and a drinking station allowed measurement of water and feed intakes during the experiment. Each pig had an ear tag in order to be detected when close to the trough. A fence prevented two pigs from being present at the same time near the trough. Pigs were weighed in the morning of days 1, 6, 13 and 14. At the start of the measurement period (day 1), the average BW was 21.2 (SD 1.4) kg. Animals were offered ad libitum a standard pelleted diet (Table 1) over the adaptation period and the first $12 \mathrm{~d}$ of the measurement period and fasted over day 13. The photoperiod was set at $12 \mathrm{~h}$ light (08.00-20.00 hours). Water was available from a nipple drinker located at a distance of $2 \mathrm{~m}$ opposite the trough.

The experiment consisted of measuring the feeding behaviour and heat production at one of the two temperatures over twelve and thirteen consecutive days respectively. Values for day 1 and day 6 (weighing days) were excluded from the data set. Three periods (days 2-5, 7-9 and 10-12) were distinguished, to account for the rapidly changing $\mathrm{BW}$ of the pigs during the experimental period.

\section{Behaviour}

Measurements. The equipment was the same as that described by Quiniou et al. (2000). Brief, variables
Table 1. Ingredients and chemical composition of the diet offered to group-housed pigs

\begin{tabular}{|c|c|}
\hline \multicolumn{2}{|l|}{ Ingredients $(\mathrm{g} / \mathrm{kg})$} \\
\hline Maize & $280 \cdot 5$ \\
\hline Soyabean meal & $255 \cdot 0$ \\
\hline Wheat & 232.5 \\
\hline Barley & $145 \cdot 0$ \\
\hline Fish meal & $50 \cdot 0$ \\
\hline Dicalcium phosphate & $18 \cdot 0$ \\
\hline Calcium carbonate & $9 \cdot 0$ \\
\hline Mineral and vitamin mixture & $5 \cdot 0$ \\
\hline Salt & $4 \cdot 0$ \\
\hline Lysine hydrochloride & 0.5 \\
\hline Fungicide & 0.5 \\
\hline $\mathrm{DM}(\mathrm{g} / \mathrm{kg})$ & 884 \\
\hline \multicolumn{2}{|l|}{ Analysed levels (g/kg DM) } \\
\hline Ash & 78 \\
\hline Crude protein $(\mathrm{N} \times 6.25)$ & 248 \\
\hline Crude fibre & 31 \\
\hline Starch & 437 \\
\hline Fat & 29 \\
\hline \multicolumn{2}{|l|}{ Energy values (MJ/kg DM) } \\
\hline Gross energy & $18 \cdot 3$ \\
\hline Metabolisable energy* & $16 \cdot 1$ \\
\hline Net energy† & 11.8 \\
\hline
\end{tabular}

concerning feed intake behaviour were recorded daily and included pig number, times at the initiation and the end of the instability of weight of the trough (i.e. visit), and feed consumption during each visit. Physical activity of the group was recorded using force sensors (type 9104A; Kistler, Winterthur, Switzerland) on which the metabolism cage was mounted.

Calculations. Several visits can occur within the same meal, with short pauses detected by the computer as a 'steady weight' of the trough. To allow comparisons to be made between studies carried out under various conditions, successive visits were combined according to a meal criterion (Bigelow \& Houpt, 1988; Labroue et al. 1994). Two successive visits, separated by an interval longer than the meal criterion, were considered as belonging to two different meals. Based on data of the present experiment, $91 \%$ of the individual estimated meal criteria was below 2 min. This value, also reported by Quiniou et al. (2000) in heavier pigs, was used as the meal criterion in further calculations.

The feeding behaviour was described for each pig by the daily number of meals, the duration and amount of feed consumed and the feeding rate. Ingestion time was calculated as the cumulative duration of visits, and consumption time as the cumulative duration of meals. These calculations were carried out for the day and the night periods.

The recorded physical activity was based on the average signal of the force sensors during a $10 \mathrm{~s}$ interval. Data were analysed to distinguish different types of activity such as long periods of relative calm (e.g. resting) from short, intense movements (e.g. fighting or locomotion). Five arbitrary classes of activity (based on the signal of the force sensors) were defined, allowing quantification of the intensity of physical activity for each class of activity. 


\section{Heat production}

Measurements. An open-circuit respiration chamber $\left(12 \mathrm{~m}^{3}\right)$ based on a design similar to that of Vermorel et al. (1973) was used. Both temperature and relative humidity were maintained constant $\left(23\right.$ or $33^{\circ} \mathrm{C}$ and 70 or $60 \%$ relative humidity respectively) during the experiment. Gas $\left(\mathrm{CO}_{2}\right.$ and $\left.\mathrm{O}_{2}\right)$ contents of ingoing and outgoing air and ventilation rate (and weight of the trough and physical activity, see earlier) were continuously and simultaneously recorded over $10 \mathrm{~s}$ intervals during the $13 \mathrm{~d}$ experimental period.

Calculations. Calculations were carried out according to the model of van Milgen et al. (1997). This relates observed changes in $\mathrm{O}_{2}$ and $\mathrm{CO}_{2}$ concentrations in the respiration chamber to physical aspects of gas exchange and to $\mathrm{O}_{2}$ consumption and $\mathrm{CO}_{2}$ production by the animals; the ACSL/Optimize software (version 2.4; AEgis Simulation, Inc., Hurtsuille, AL, USA) was used. Heat production was calculated from gas exchanges according to the formula of Brouwer (1965). In the present experiment a large number of visits to the trough were recorded (on average 240/d and group) and they were strongly correlated with peaks of physical activity. It was therefore impossible to estimate simultaneously heat production associated with physical activity $\left(\mathrm{HP}_{\mathrm{act}}\right)$ and the short term TEF. To circumvent this problem, the heat production per unit force was estimated only during fasting and it was assumed that this value was independent of BW and feeding status. The product of this variable and the actual daily force measured in fed pigs provided an estimate of daily $\mathrm{HP}_{\text {act }}$. Measurements of heat production in fasting animals allowed the calculation of fasting heat production $\left(\mathrm{HP}_{\mathrm{fas}}\right)$. It was assumed that the $\mathrm{HP}_{\text {fas }}$ value obtained on the last measurement day was applicable to fed animals during the previous $12 \mathrm{~d}$ (based on the estimated $\mathrm{BW}$ for each day and assuming a constant $\mathrm{HP}_{\text {fas }}$ on a per kg metabolic $\mathrm{BW}\left(\mathrm{BW}^{0.60}\right)$ basis). TEF was the difference between $\mathrm{HP}_{\text {tot }}$ and the sum of $\mathrm{HP}_{\mathrm{act}}$ and $\mathrm{HP}_{\text {fas }}$. Energy balance data were expressed as $\mathrm{MJ} / \mathrm{d}$ or per $\mathrm{kg} \mathrm{BW}^{0.60}$ (according to Noblet et al. 1999).

\section{Statistics}

Some data were measured in individual animals (e.g. feeding behaviour, feed intake), whereas other data were measured for a group of animals (e.g. heat production). In the analysis all results are reported on a 'per pig' basis. Performance data (BW, BW gain, VFI, voluntary water intake and feed conversion ratio), as measured between days 1 and 12, and individual feeding behaviour were analysed using the general linear models procedure of Statistical Analysis Systems (release 6.07; SAS Institute Inc., Cary, NC, USA). To account for the rapidly-changing BW of the animals, the experimental period was divided in to three sub-periods (period 1 , days $2-5$, period 2 , days $7-$ 9; period 3; days 10-12). The individual components of feeding behaviour (per period) were subjected to ANOVA with temperature, period, their interaction, the interaction of temperature and the group, and the interaction of temperature, group and animal as main effects, and using temperature $\times$ group as the error term for testing temperature, and temperature $\times$ group $\times$ animal as the error term for testing temperature $\times$ group. The diurnal percentage of total activity was calculated from the measurements per group and analysed with temperature, period, temperature $\times$ period and temperature group as main effects, and temperature $\times$ group as the error term for testing temperature.

The overall effect of temperature (for the whole experimental period) on mean VFI, heat production and its components, retained energy and RQ was analysed by ANOVA. To account for the changing BW during the experiment, data (per period) were analysed using temperature, period, their interaction and the temperature $\times$ group interaction as main effects. The latter term was used as the error term to test the effect of temperature.

\section{Results \\ Performance}

As expected, VFI was reduced at $33^{\circ} \mathrm{C}$ (Table 2), being $30 \%$ lower than at $23^{\circ} \mathrm{C}$ with subsequent lower BW gain at $33^{\circ} \mathrm{C}$ than at $23^{\circ} \mathrm{C}(621 \mathrm{~g} / \mathrm{d} v .987 \mathrm{~g} / \mathrm{d})$. In addition, the feed conversion ratio was significantly lower at $23^{\circ} \mathrm{C}$ than at $33^{\circ} \mathrm{C}$ $(1.50$ v. $1.68 ; P<0.05)$. Despite the lower feed intake, there was a tendency for increased water consumption at $33^{\circ} \mathrm{C}$.

Table 2. Effect of temperature $(T)$ on performance of group-housed young pigs over the experimental period $\dagger$

(values are expressed per pig)

\begin{tabular}{|c|c|c|c|c|}
\hline & \multicolumn{2}{|c|}{$\mathrm{T}\left({ }^{\circ} \mathrm{C}\right)$} & \multirow[b]{2}{*}{ Residual SD } & \multirow{2}{*}{$\begin{array}{c}\text { Statistical significance } \\
\text { of effect of } T\end{array}$} \\
\hline & 23 & 33 & & \\
\hline No. of observations $\ddagger$ & 3 & 3 & & \\
\hline Initial body weight $(\mathrm{kg}) \S$ & 21.4 & 20.9 & 0.4 & \\
\hline Final body weight $(\mathrm{kg}) \S$ & 33.2 & 28.4 & 0.8 & ** \\
\hline Fasting body weight $(\mathrm{kg}) \S$ & $30 \cdot 8$ & $26 \cdot 9$ & 1.0 & ** \\
\hline Body weight gain $(\mathrm{g} / \mathrm{d})$ & 987 & 621 & 49 & ** \\
\hline Voluntary feed intake $(\mathrm{g} / \mathrm{d})$ & 1483 & 1045 & 74 & ** \\
\hline Voluntary water intake $(\mathrm{g} / \mathrm{d})$ & 4408 & 5863 & 2595 & \\
\hline Feed: gain & 1.50 & 1.68 & 0.07 & * \\
\hline
\end{tabular}


Table 3. Effects of temperature $(T)$ and period $(P)$ on individual components of the feeding behaviour of group-housed young pigst

\begin{tabular}{|c|c|c|c|c|c|c|c|c|c|c|c|c|}
\hline \multirow{2}{*}{$\begin{array}{l}\mathrm{T}\left({ }^{\circ} \mathrm{C}\right) \\
\mathrm{P} \ddagger\end{array}$} & \multicolumn{3}{|c|}{23} & \multicolumn{3}{|c|}{33} & \multirow[b]{2}{*}{$\sigma_{1}\|\|$} & \multirow[b]{2}{*}{$\sigma_{2}$ ๆी } & \multicolumn{4}{|c|}{ Statistical significance of effect of††† } \\
\hline & 1 & 2 & 3 & 1 & 2 & 3 & & & $\mathrm{~T}$ & $\mathrm{P}$ & $\mathrm{T} \times \mathrm{P}$ & $\mathrm{T} \times \mathrm{G}$ \\
\hline No. of observations§ & 15 & 15 & 15 & 15 & 15 & 15 & & & & & & \\
\hline Duration of $P(\mathrm{~d})$ & 4 & 3 & 3 & 4 & 3 & 3 & & & & & & \\
\hline Mean body weight $(\mathrm{kg})$ & $23 \cdot 6$ & $28 \cdot 0$ & 31.5 & $22 \cdot 7$ & 25.5 & $27 \cdot 4$ & 0.4 & 3.0 & * & $\star *$ & ** & \\
\hline \multicolumn{13}{|c|}{ Mean components of daily feeding behaviour } \\
\hline No. of visits\| & 55 & 58 & 57 & 38 & 40 & 39 & 9 & 53 & & & & \\
\hline No. of meals? & $14 \cdot 8$ & $14 \cdot 0$ & $14 \cdot 2$ & $14 \cdot 7$ & $15 \cdot 8$ & $13 \cdot 8$ & $2 \cdot 2$ & 9.9 & & & & \\
\hline Feed intake $(\mathrm{g})$ & 1290 & 1576 & 1710 & 967 & 1129 & 1095 & 174 & 250 & ** & $\star *$ & ** & \\
\hline Feed intake $\left(\mathrm{g} / \mathrm{kg} \mathrm{BW}^{0.60}\right)$ & 194 & 214 & 215 & 148 & 161 & 150 & 24 & 30 & ** & * & & \\
\hline Ingestion time $\dagger+(\min )$ & 56 & 57 & 59 & 43 & 43 & 40 & 6 & 5 & ** & & & \\
\hline Consumption timeł‡ (min) & 77 & 81 & 80 & 53 & 55 & 51 & 8 & 38 & * & & & \\
\hline Rate of feed intake ( $\mathrm{g} / \mathrm{min})$ & 23 & 28 & 30 & 23 & 27 & 28 & 3 & 9 & & ** & & \\
\hline Rate of feed intake $\left(\mathrm{g} / \mathrm{min}\right.$ per $\left.\mathrm{kg} \mathrm{BW} \mathrm{B}^{0.60}\right)$ & 3.5 & 3.8 & 3.7 & 3.6 & 3.9 & 3.8 & 0.4 & 1.2 & & ** & & \\
\hline \multicolumn{13}{|l|}{ Characteristics of the meal } \\
\hline Meal size $(\mathrm{g})$ & 93 & 123 & 132 & 69 & 78 & 86 & 16 & 60 & * & $\star \star$ & * & \\
\hline Meal size $\left(\mathrm{g} / \mathrm{kg} \mathrm{BW}^{0.60}\right)$ & 13.9 & $16 \cdot 6$ & $16 \cdot 6$ & $10 \cdot 7$ & $11 \cdot 2$ & 11.8 & $2 \cdot 1$ & 8.9 & & ** & & \\
\hline Ingestion time (min) & $4 \cdot 1$ & 4.5 & 4.6 & $3 \cdot 1$ & 3.0 & $3 \cdot 1$ & 0.5 & $2 \cdot 8$ & & & & \\
\hline Consumption time (min) & 5.5 & $6 \cdot 3$ & $6 \cdot 1$ & 3.9 & 3.7 & 4.0 & 0.7 & $5 \cdot 2$ & & & & ** \\
\hline \multicolumn{13}{|l|}{ Diurnal feeding behaviour ( $\%$ total) } \\
\hline No. of meals & 67 & 66 & 65 & 64 & 66 & 67 & 7 & 9 & & & & \\
\hline Feed intake & 67 & 66 & 66 & 64 & 68 & 70 & 6 & 13 & & & & \\
\hline Ingestion time & 67 & 66 & 65 & 63 & 69 & 69 & 7 & 13 & & & & \\
\hline Diurnal physical activity (\% total)§§ & 68 & 66 & 65 & 61 & 55 & 49 & 8 & 5 & * & & & \\
\hline
\end{tabular}

$\mathrm{BW}^{0.60}$, metabolic body weight; $\mathrm{G}$, group.

${ }^{\star} P<0.05,{ }^{* *} P<0.01$.

† For details of animals and procedures, see p. 64

‡ P 1 included days $2-5$, P 2 included days $7-9$, P 3 included days 10-12. Days 1 and 6 were not taken into account (weighing days).

$\S$ Each observation was the mean over 3 or $4 \mathrm{~d}$ for one pig (five pigs per group).

II Duration of instability of the trough.

I One meal corresponded to a group of successive visits separated by $<2$ min (i.e. meal criterion).

t† Cumulative duration of the visits.

$\ddagger \ddagger$ Cumulative duration of the eating and non-eating sessions within meals.

$\S \S$ Observation was physical activity of the group and the model included the effects of $T, P$, their interaction $(T \times P)$ and the effect of the group within temperature $(G(T))$; the error for testing $T$ effect was $G(T)$.

\|\| Residual standard error for testing the effect of $P$.

१ी Residual standard error for testing the effect of $T$.

t†† The model included the effects of $T, P$, their interaction $(T \times P)$, the interaction of $T$ with $G(T \times G)$ and the interaction of $G$ with $T$ and animal $(A ; T \times G \times A)$; the errors for testing $T$ and $T \times G$ effects were $T \times G$ and $T \times G \times A$, respectively. The effect of $T \times G \times A$ was significant whatever the component of feeding behaviour considered $(P<0.01)$, except for the percentage of diurnal ingestion time $(P>0.05)$.

\section{Behaviour}

The effects of temperature, period and their interaction on components of feeding behaviour are given in Table 3 . The decrease of $30 \%$ in feed intake at $33^{\circ} \mathrm{C}$ was associated with shorter daily ingestion time $(-28 \%)$ and consumption time $(-34 \%)$ at $33^{\circ} \mathrm{C}$. However, the daily number of meals and the rate of feed intake were not affected by temperature, so that meal size was significantly lower at $33^{\circ} \mathrm{C}(P<0 \cdot 05)$. The difference between consumption time and ingestion time was smaller at $33^{\circ} \mathrm{C}$, which suggests that pigs spent more time near the trough at thermoneutrality than at high temperature. The duration of the meals (consumption time) was numerically decreased at $33^{\circ} \mathrm{C}$ (3.9 $\min v .5 .9 \mathrm{~min}$, on average).

The partitioning of feeding activity between day (67\%) and night $(33 \%)$ was not affected by temperature. Twothirds of physical activity (force) was recorded during the day at $23^{\circ} \mathrm{C}$. At $33^{\circ} \mathrm{C}$ there was a more uniform partitioning between diurnal and nocturnal activity. Even though heat production associated with physical activity was not affected by ambient temperature, the characteristics of physical activity differed between the two temperatures (Fig. 1). The physical activity in pigs kept at $23^{\circ} \mathrm{C}$ appeared to be more extreme (either very calm or very active) compared with that of pigs kept at $33^{\circ} \mathrm{C}$. It can be assumed that the highest levels corresponded to the standing position and locomotion, while the lower levels corresponded mainly to respiration in the lying position.

As anticipated, period affected VFI (g/d), but there was a significant interaction between period and temperature (Table 3). In other words, VFI increased regularly over successive periods at $23^{\circ} \mathrm{C}$, whereas the increase was quite small at $33^{\circ} \mathrm{C}$. These changes in daily VFI over the experiment were achieved through an increased meal size. The rate of feed intake increased from 23 to $29 \mathrm{~g} / \mathrm{min}$ on average between period 1 and period 3 , irrespective of the temperature.

Meal size and VFI, when expressed as $\mathrm{g} / \mathrm{kg} \mathrm{BW} \mathrm{BW}^{0 \cdot 60}$, increased slightly over the experiment. However, the interaction previously observed between temperature and period for VFI and meal size was not significant.

\section{Heat production and its components}

Data on heat production in the fed and fasting states over the experimental period are given in Table 4. Pigs exposed at $33^{\circ} \mathrm{C}$ had a lower fasting heat production expressed per $\mathrm{kg} \mathrm{BW}^{0.60}(-14 \%)$ than those kept at $23^{\circ} \mathrm{C}$. In fed pigs the 


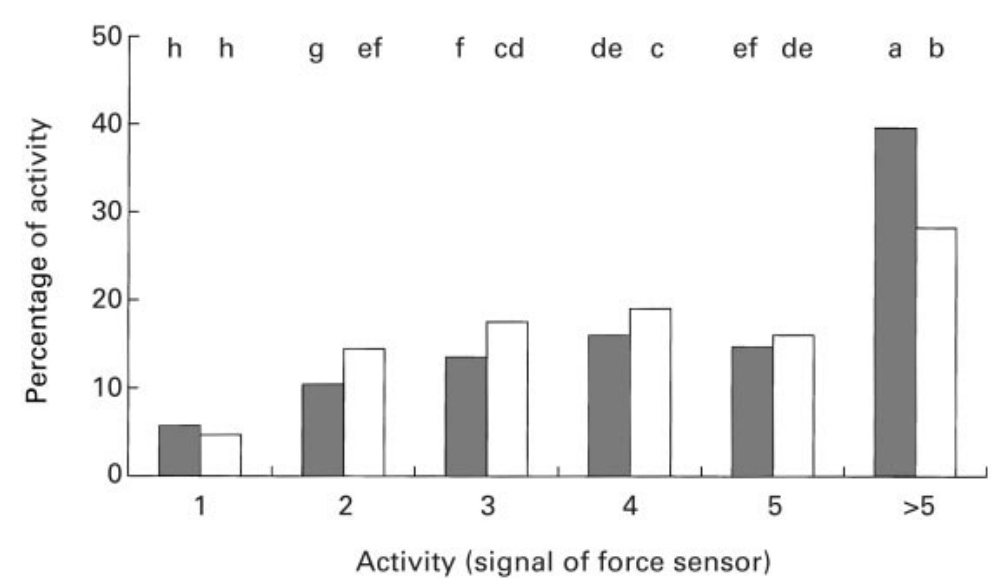

Fig. 1. Repartitioning of physical activity (signal of force sensor) at $23^{\circ} \mathrm{C}(\square)$ or $33^{\circ} \mathrm{C}(\square)$ in group-housed young pigs. $\mathrm{a}, \mathrm{b}, \mathrm{c}, \mathrm{d}, \mathrm{e}, \mathrm{f}, \mathrm{g}$ Mean values with unlike superscript letters were significantly different $(P<0 \cdot 05)$. For details of animals and procedures, see p. 64

increase in ambient temperature from 23 to $33^{\circ} \mathrm{C}$ resulted in a $22 \%$ decrease in $\mathrm{HP}_{\text {tot }}$. The contributions of $\mathrm{HP}_{\text {act }}$, $\mathrm{TEF}$ and $\mathrm{HP}_{\text {fas }}$ variations to the decrease in $\mathrm{HP}_{\text {tot }}$ with temperature rise were 10,45 and $45 \%$ respectively; the reductions were significant for TEF and $\mathrm{HP}_{\text {fas }}$ only $(P<0.05$ in both cases). The reduction in TEF was not due to a decrease in TEF per $\mathrm{g}$ feed $(2 \mathrm{~kJ} / \mathrm{g}$ at both temperatures), but essentially to the effect of VFI reduction. The RQ was significantly lower at $33^{\circ} \mathrm{C}(1.08 \mathrm{v} .1 \cdot 12$; $P<0.05$ ).

As indicated in Table 5, total metabolisable energy intake, $\mathrm{HP}_{\text {tot }}, \mathrm{HP}_{\text {act }}$ and retained energy increased over the experiment, but the variation was smaller at $33^{\circ} \mathrm{C}$ than at $23^{\circ} \mathrm{C}$ for total metabolisable energy intake and retained energy. When expressed per $\mathrm{kg} \mathrm{BW}^{0.60}$, total metabolisable energy intake, $\mathrm{HP}_{\text {tot }}$, its components (except $\mathrm{HP}_{\mathrm{act}}$ ) and retained energy were reduced at $33^{\circ} \mathrm{C}$ (Table 5).

\section{Discussion \\ Performance}

The results of the present experiment demonstrate a clear decrease in VFI and, subsequently, in BW gain at $33^{\circ} \mathrm{C}$. The comparison of results obtained at 23 and $33^{\circ} \mathrm{C}$ indicates that VFI declined by $45 \mathrm{~g} / \mathrm{d}$ per ${ }^{\circ} \mathrm{C}$, which is similar to the $39 \mathrm{~g} / \mathrm{d}$ per ${ }^{\circ} \mathrm{C}$ calculated from a previous study (Collin et al. 2001), and to results of Sugahara et al. $\left(1970 ; 42 \mathrm{~g} / \mathrm{d} \mathrm{per}{ }^{\circ} \mathrm{C}\right)$ in young growing pigs. However, this decrease is greater than that reported by Rinaldo \& Le

Table 4. Effect of temperature on voluntary feed intake, heat production and its components in group-housed young pigs $†$

\begin{tabular}{|c|c|c|c|c|}
\hline & \multicolumn{2}{|c|}{$\mathrm{T}\left({ }^{\circ} \mathrm{C}\right)$} & \multirow[b]{2}{*}{ Residual SD } & \multirow[b]{2}{*}{ Statistical significance of effect of temperature†† } \\
\hline & 23 & 33 & & \\
\hline No. of observations $\ddagger$ & 3 & 3 & & \\
\hline Body weight (BW; kg) & $27 \cdot 3$ & 24.9 & 0.8 & * \\
\hline \multicolumn{5}{|l|}{ Fed state } \\
\hline Voluntary feed intake $(\mathrm{g} / \mathrm{d})$ & 1502 & 1054 & 69 & ** \\
\hline Metabolisable energy intake (MEl; MJ/d) & 21.69 & $15 \cdot 13$ & 0.99 & ** \\
\hline \multicolumn{5}{|l|}{ Heat production $(\mathrm{MJ} / \mathrm{d})$} \\
\hline Activity & $2 \cdot 01$ & 1.76 & 0.19 & \\
\hline Thermic effect of feed & $3 \cdot 10$ & $2 \cdot 00$ & 0.34 & * \\
\hline Fasting heat production§ & $6 \cdot 12$ & 5.01 & 0.34 & * \\
\hline Total & $11 \cdot 23$ & 8.77 & 0.43 & ** \\
\hline Retained energy (MJ/d) & 10.45 & $6 \cdot 36$ & 0.59 & ** \\
\hline $\mathrm{RQ}$ & $1 \cdot 12$ & 1.08 & 0.01 & * \\
\hline \multicolumn{5}{|l|}{ Thermic effect of feed $(\mathrm{kJ})$} \\
\hline /kg feed & $2 \cdot 05$ & 1.87 & 0.27 & \\
\hline /kJ ME & 0.14 & 0.13 & 0.02 & \\
\hline$/ \mathrm{kJ} \mathrm{MEI}_{\mathrm{O}} \|$ & 0.17 & 0.15 & 0.03 & \\
\hline Fasting heat production $\|,\left(\mathrm{kJ} / \mathrm{d}\right.$ per $\mathrm{kg} \mathrm{BW}^{0 \cdot 60}$ ) & 849 & 728 & 49 & * \\
\hline
\end{tabular}

${ }^{\star} P<0.05,{ }^{* *} P<0.01$.

† For details of animals and procedures, see p. 64.

$\ddagger$ One observation corresponds to data measured in a group of five pigs; the data is expressed per pig.

$\S$ Estimated from fasting heat production measured on day 14

II MEI - heat production for activity.

If Calculated with BW of fed pigs (morning of day 13) as reference.

†† Days 1 and 6 were not taken into account (weighing days). 
Table 5. Effect of temperature $(T)$ and period $(P)$ on heat production and its components in group-housed young pigs $\dagger$

\begin{tabular}{|c|c|c|c|c|c|c|c|c|c|c|c|c|}
\hline \multirow{2}{*}{$\begin{array}{l}\mathrm{T}\left({ }^{\circ} \mathrm{C}\right) \\
\mathrm{P} \ddagger\end{array}$} & \multicolumn{3}{|c|}{23} & \multicolumn{3}{|c|}{33} & \multirow[b]{2}{*}{$\sigma_{1} \S$} & \multirow[b]{2}{*}{$\sigma_{2} \|$} & \multicolumn{4}{|c|}{ Statistical signifiance of effect of } \\
\hline & 1 & 2 & 3 & 1 & 2 & 3 & & & $\mathrm{~T}$ & $\mathrm{P}$ & $\mathrm{T} \times \mathrm{P}$ & $\mathrm{G}(\mathrm{T})$ \\
\hline Mean body weight $(\mathrm{kg})$ & $23 \cdot 6$ & $28 \cdot 0$ & 31.5 & $22 \cdot 7$ & $25 \cdot 5$ & $27 \cdot 4$ & 0.3 & $1 \cdot 3$ & * & ** & ** & ** \\
\hline Voluntary feed intake $(\mathrm{g} / \mathrm{d})$ & 1290 & 1576 & 1711 & 967 & 1128 & 1095 & 72 & 111 & ** & ** & * & \\
\hline Metabolisable energy intake (MEI; MJ/d) & $18 \cdot 62$ & $2 \quad 22 \cdot 76$ & 24.71 & $13 \cdot 88$ & $16 \cdot 20$ & $15 \cdot 72$ & 1.05 & 1.61 & ** & ** & * & \\
\hline \multicolumn{13}{|l|}{ Heat production $(\mathrm{MJ} / \mathrm{d})$} \\
\hline Activity & 1.81 & $2 \cdot 07$ & $2 \cdot 21$ & 1.57 & 1.86 & 1.93 & 0.07 & 0.32 & & ** & & ** \\
\hline Thermic effect of feed & 2.44 & 3.34 & $3 \cdot 74$ & 1.72 & $2 \cdot 23$ & $2 \cdot 15$ & 0.38 & 0.55 & * & ** & & \\
\hline Fasting heat production & $5 \cdot 62$ & $6 \cdot 23$ & 6.69 & 4.73 & 5.07 & $5 \cdot 30$ & & & & & & \\
\hline Total & 9.87 & $7 \quad 11.64$ & $12 \cdot 64$ & 8.02 & $9 \cdot 16$ & $9 \cdot 38$ & 0.43 & 0.72 & ** & ** & & \\
\hline Retained energy $(\mathrm{MJ} / \mathrm{d})$ & 8.75 & $5 \quad 11.12$ & $12 \cdot 07$ & 5.86 & 7.04 & $6 \cdot 34$ & 0.66 & 0.94 & ** & ** & * & \\
\hline \multicolumn{13}{|l|}{ Energy balance $\left(\mathrm{kJ} / \mathrm{kg} \mathrm{BW}^{0.60}\right.$ per d) } \\
\hline $\mathrm{MEI}$ & 2744 & 3030 & 3103 & 2132 & 2328 & 2168 & 147 & 174 & ** & & & \\
\hline \multicolumn{13}{|l|}{ Heat production } \\
\hline Activity & 271 & 281 & 279 & 241 & 266 & 265 & 11 & 38 & & * & & ** \\
\hline Thermic effect of feed & 367 & 452 & 473 & 262 & 319 & 294 & 54 & 79 & * & & & \\
\hline Total & 1482 & 1577 & 1595 & 1231 & 1312 & 1286 & 59 & 68 & ** & & & \\
\hline Retained energy & 1312 & 1507 & 1523 & 900 & 1009 & 869 & 95 & 114 & ** & & & \\
\hline $\mathrm{RQ}$ & $1 \cdot 10$ & $\quad 1.11$ & $1 \cdot 14$ & 1.08 & 1.09 & 1.08 & 0.01 & 0.02 & * & & & \\
\hline
\end{tabular}

${ }^{\star} P<0.05,{ }^{* *} P<0.01$

† For details of animals and procedures, see p. 64

¥ $\mathrm{P} 1$ included days $2-5,3-5, \mathrm{P} 2$ included days $7-9, \mathrm{P} 3$ included days $10-12$. One observation corresponds to data measured in a group of five pigs; data is expressed per pig.

$\S$ Residual standard error for testing the $P$ effect.

II Residual standard error for testing the T effect.

I The model included the effects of $T, P$, group within- $T G(T)$, the error being $G(T)$.

Dividich $\left(1991 \mathrm{a} ; 28 \mathrm{~g} / \mathrm{d}\right.$ per $\left.{ }^{\circ} \mathrm{C}\right)$ between 25 and $31 \cdot 5^{\circ} \mathrm{C}$ in young pigs between 9 and $30 \mathrm{~kg}$. The reduction in BW gain due to temperature (or feed intake) corresponded to $37 \mathrm{~g} / \mathrm{d}$ per ${ }^{\circ} \mathrm{C}$, which is greater than that reported in other studies in young pigs $\left(20 \mathrm{~g} / \mathrm{d}\right.$ per ${ }^{\circ} \mathrm{C}$ according to Sugahara et al. (1970) and Rinaldo \& Le Dividich (1991a)). The reasons for this discrepancy could be the higher initial BW $(21 \mathrm{~kg}$ v. $9 \mathrm{~kg}$ ) in the present experiment. Also, in the present experiment pigs were housed in groups, which may stimulate feed intake, at least at thermoneutrality. In addition, the relatively high BW gain and VFI recorded at $23^{\circ} \mathrm{C}$ could also have induced accentuated effects of heat exposure.

\section{Feeding behaviour}

Feed intake and feeding patterns in growing pigs are affected not only by physiological, genetic and social factors (Bigelow \& Houpt, 1988; Labroue et al. 1994), but also by environmental factors (Nienaber \& Hahn, 1982; Le Dividich et al. 1998; Quiniou et al. 2000). In the present study, pigs acclimatised to the hot environment by reducing their feed intake $\left(-3.0 \% /{ }^{\circ} \mathrm{C}\right)$, which is consistent with the decrease described by Quiniou et al. (2000) in heavier pigs $\left(-3.4 \% /{ }^{\circ} \mathrm{C}\right)$. Chronic exposure to $33^{\circ} \mathrm{C}$ also affected other components of feeding behaviour in pigs. Ingestion time per $\mathrm{d}$ and occupation time of the feeding station were reduced, and the duration of non-eating sessions within meals at $23^{\circ} \mathrm{C}(22 \mathrm{~min})$ was twice that at $33^{\circ} \mathrm{C}(11 \mathrm{~min})$. Temperature did not seem to affect the daily number of meals, which is consistent with results of Nienaber et al. (1993) and Quiniou et al. (2000), also obtained in grouphoused animals.

The reduction in VFI at $33^{\circ} \mathrm{C}$ can be partly explained by a reduction in $\mathrm{BW}$, which is the combined result of the hot environment and the decrease in VFI. Consistent with results reported by Bigelow \& Houpt (1988) in young growing pigs, and by Nienaber et al. (1990), Labroue et al. (1994) and Quiniou et al. (2000) in heavier pigs, ingestion time and consumption time remained relatively constant during the trial, whereas the rate of feed intake increased. Meal size increased with BW (period), whereas the number of meals remained constant, so that the total VFI increased. The number of meals calculated from the present experiment (fifteen meals/d) is higher than the nine to eleven daily meals calculated in heavier pigs (Xin \& DeShazer, 1991; Nienaber et al. 1996; Quiniou et al. 2000). It is consistent with results of Quiniou et al. (1999), who found a decrease in the number of meals with increasing BW. The period effect on feed intake (Table 5) was mainly due to the increased BW over successive periods. The significant interaction between temperature and period on feed intake $(P<0.05)$ illustrates the smaller increase at the highest temperature, which may suggest a long-term acclimation effect to high temperature.

Feeding behaviour was mainly diurnal, with two-thirds of the feed consumed during the day, and was not affected by ambient temperature. This value is similar to that reported by Labroue et al. (1994) and Quiniou et al. $(2000 a)$ in growing pigs kept under similar conditions. Studies converge to show that the main factor determining the partitioning of VFI between day and night on a given light pattern is BW, feeding behaviour of pigs becoming more diurnal with increasing BW (Bigelow \& Houpt, 1988; Labroue et al. 1994; Quiniou et al. 1999). Although high temperature induced a decrease in the diurnal percentage of number of meals in the study of Quiniou et al. (2000), it did not change the partitioning between day and night in our 
study. It appears that, as a result of heat stress, heavier pigs shift a part of their meals to the night, which has been described in studies with cyclic temperatures mimicking real daily temperatures (Feddes et al. 1989; Xin \& DeShazer, 1991).

\section{Acclimation to high temperatures}

Acclimation to high temperature results in both increased evaporative heat loss and decreased heat production. The first mechanism is limited in pigs, owing to the low capacity for cutaneous evaporative heat loss. As expected, results of the present experiment indicated a great reduction in heat production when pigs were exposed to $33^{\circ} \mathrm{C}$, which agrees with the findings of studies by Stombaugh \& Grifo (1977), Nienaber \& Hahn (1982), Nienaber et al. (1987) and Quiniou et al. (2001) in heavier pigs. Gray \& McCracken (1974) in $22 \mathrm{~kg}$ pigs obtained similar heat production values at 22 and $29^{\circ} \mathrm{C}$, but their experiment was carried out to ensure similar daily intakes.

The reduced TEF contributed to $45 \%$ of the decrease in $\mathrm{HP}_{\text {tot }}$ at $33^{\circ} \mathrm{C}$, resulting directly from the decreased VFI. The second factor contributing to the decrease in $\mathrm{HP}_{\text {tot }}$ was the $\mathrm{HP}_{\text {fas }}(45 \%)$. This finding conflicts with data from Holmes (1974), who did not observe such a decrease in heavier pigs during a $48 \mathrm{~h}$ fast, despite different preceding feeding levels. It can be hypothesised that, in our study, $\mathrm{HP}_{\text {fas }}$ was overestimated at $23^{\circ} \mathrm{C}$ because pigs suffered from cold. However, Bernier et al. (1996) showed that $\mathrm{HP}_{\text {fas }}$ was constant at and above $24^{\circ} \mathrm{C}$ in individuallyhoused 30-50 kg pigs fed at constant feeding levels before $\mathrm{HP}_{\text {fas }}$ measurements. An alternative explanation for decreased $\mathrm{HP}_{\text {fas }}$ at $33^{\circ} \mathrm{C}$ is the decrease in the viscera mass (Rinaldo \& Le Dividich, 1991a) and the associated decrease in heat production (Koong et al. 1983; van Milgen et al. 1998) resulting from the lower feeding level. Viscera make an important contribution to $\mathrm{HP}_{\text {fas }}$, and $24 \mathrm{~h}$ of fasting may not be sufficient to attenuate differences in visceral mass and heat production. Summarising, the reduction in heat production at high ambient temperatures seems to be the result of both direct (TEF) and indirect $\left(\mathrm{HP}_{\mathrm{fas}}\right)$ effects of reduced feed intake.

The contribution of $\mathrm{HP}_{\text {act }}$ to total metabolisable energy intake $(9 \%)$ and to $\mathrm{HP}_{\text {tot }}(18 \%)$ at $23^{\circ} \mathrm{C}$ was slightly higher than results obtained by Quiniou et al. (2001) at thermoneutrality ( $8 \%$ of the total metabolisable energy intake and $14 \%$ of the $\mathrm{HP}_{\text {tot }}$ ) in $30-90 \mathrm{~kg}$ pigs. At $33^{\circ} \mathrm{C}$, corresponding values were higher (12 and $20 \%$ respectively) partly in connection with the reduced total metabolisable energy intake at this temperature. In the present study $\mathrm{HP}_{\text {act }}$ was lower at $33^{\circ} \mathrm{C}$ and the variation contributed to $10 \%$ of the $\mathrm{HP}_{\text {tot }}$ decrease. Results of Quiniou et al. (2001) suggested a tendency for increased $\mathrm{HP}_{\mathrm{act}}$ at high ambient temperature, in connection with intense panting of animals under heat stress. The results of the present study also support this hypothesis, as shown in Fig. 1. As indicated earlier, the upper values of activity were associated with walking or standing, whereas the lower values were associated with resting or lying. Panting can be considered an intermediate level of activity. Pigs kept at $33^{\circ} \mathrm{C}$ seem to reduce energy expenditure by avoiding voluntary movements, as in having long intervals between visits within a meal (Quiniou et al. 2000; the present study). Standing appears to be very energy expensive in pigs (Dauncey, 1990; Noblet et al. 1993; van Milgen et al. 1998) and the reduction in non-essential activity can be considered as an adaptation to the hot environment. Although panting seems to cause an increase in activity, the benefit (heat loss) probably outweighs the cost (heat production).

The RQ is indicative of the proportional rates of substrates used for catabolism and anabolism. Catabolism of substrates (e.g. for ATP synthesis) results in an RQ $\leq 1$, whereas fatty acid synthesis results in an $R Q>1$. The observed RQ is a combination of both catabolism and anabolism, and the RQ in growing pigs is almost always $>1$. The exposure to $33^{\circ} \mathrm{C}$ resulted in a reduction in both feed intake and energy retention (and thus reduced fatty acid synthesis). Similar results were found by Rinaldo \& Le Dividich $(1991 b)$, and are probably the cause of the reduced $R Q$ at $33^{\circ} \mathrm{C}$.

In conclusion, the present study provides some evidence that the reduction in heat production in heat-stressed young pigs is essentially caused by a reduction in the TEF and $\mathrm{HP}_{\text {fas }}$. Both effects are directly related to a marked reduction in VFI at high ambient temperatures. This finding implies that nutritional adjustments, such as a reduction in the fibre or protein content of the feed, could be efficient in attenuating the negative effects of hot climatic conditions. The present results also suggest that, although $\mathrm{HP}_{\text {act }}$ was not different between 23 and $33^{\circ} \mathrm{C}$, its partitioning between voluntary movements (standing and locomotion) and breathing depends on ambient temperature.

\section{Acknowledgements}

The authors thank J. Le Dividich, N. Quiniou and D. Renaudeau for helpful discussions and suggestions, L. Delaby for statistical advice and A. Roger, H. Renoult, J. Gauthier, F. Thomas and M.T. Gauthier for technical assistance. This work was supported by grants from the Institut National de la Recherche Agronomique, Tours and Rennes.

\section{References}

Bernier J, Dubois S \& Noblet J (1996) Fasting heat production of Large White and Meishan growing pigs as influenced by environmental temperature. Journal of Animal Science $\mathbf{7 4}$, Suppl. 1, 180.

Bigelow JA \& Houpt TR (1988) Feeding and drinking patterns in young pigs. Physiology and Behavior 43, 99-109.

Brouwer E (1965) Report of the sub-committee on constants and factors. In Energy Metabolism. European Association for Animal Production Publication no 11, pp. 441-443 [KL Blaxter, editor]. London: Academic Press.

Collin A, van Milgen J \& Le Dividich J (2001) Modelling the effect of high, constant temperature on food intake in young growing pigs. Animal Science 72, (In the Press).

Dauncey MJ (1990) Activity and energy expenditure. Canadian Journal of Physiology and Pharmacology 68, 17-27.

Feddes JJR, Young BA \& DeShazer JA (1989) Influence of 
temperature and light on feeding behaviour of pigs. Applied Animal Behavioral Science 23, 215-222.

Giles LR (1992) Energy expenditure of growing pigs at high ambient temperatures. PhD Thesis, University of Sidney.

Gray R \& McCracken KJ (1974) Utilisation of energy and protein by pigs adapted to different temperature levels. In Energy Metabolism in Farm Animals. Proceedings of the 6th Symposium, Hohenheim, European Association for Animal Production Publication no. 14, pp. 161-164 [KH Menke, HJ Lantzsch and JR Reicht, editors]. Stuttgart: Universität Hohenheim.

Holmes CW (1974) Further studies on the energy and protein metabolism of pigs growing at high ambient temperature, including measurements with fasting pigs. Animal Production 19, $211-220$.

Ingram DL (1965) The effect of humidity on temperature regulation and cutaneous water loss in the young pig. Research in Veterinary Science 6, 9-17.

Koong LJ, Nienaber JA \& Mersmann AJ (1983) Effect of plane of nutrition on organ size and fasting heat production in genetically obese and lean pigs. Journal of Nutrition 113, 1626-1631.

Labroue F, Guéblez R, Sellier P \& Meunier-Salaün MC (1994) Feeding behaviour of group-housed Large-White and Landrace pigs in French central test stations. Livestock Production Science 40, 303-312.

Le Dividich J, Noblet J, Herpin P, van Milgen J \& Quiniou N (1998) Thermoregulation. In Progress in Pig Science, pp. 229-264 [JJ Wiseman, MA Varley and JP Chadwick, editors]. Nottingham: Nottingham University Press.

Nienaber JA \& Hahn GL (1982) Heat Production and Feed Intake of Ad-libitum-fed Growing Swine as Affected by Temperature. American Society of Agricultural Engineers Paper no. 82-4065, St Joseph, MIASAE.

Nienaber JA, Hahn GL, Korthals RL \& McDonald TP (1993) Eating behavior of swine influenced by environmental temperature. Transactions of the American Society of Agricultural Engineers 36, 937-944.

Nienaber JA, Hahn GL, McDonald TP \& Korthals RL (1996) Feeding patterns and swine performance in hot environments. Transactions of the American Society of Agricultural Engineers 39, 195-202.

Nienaber JA, Hahn GL \& Yen JT (1987) Thermal environment effects on growing-finishing swine. Part 1. Growth, feed intake and heat production. Transactions of the American Society of Agricultural Engineers 30, 1772-1775.

Nienaber JA, McDonald TP, Hahn GL \& Chen YR (1990) Eating dynamics of growing-finishing swine. Transactions of the American Society of Agricultural Engineers 33, 2011-2018.

Noblet J, Fortune H, Shi XS \& Dubois S (1994) Prediction of net energy value of feeds for growing pigs. Journal of Animal Science 72, 344-354.
Noblet J, Karege C, Dubois S \& van Milgen J (1999) Metabolic utilization of energy and maintenance requirements in growing pigs: effects of sex and genotype. Journal of Animal Science 77, 1208-1216.

Noblet J, Shi X \& Dubois S (1993) Energy cost of standing activity in sows. Livestock Production Science 34, 127-136.

Quiniou N, Dubois S, Le Cozler Y, Bernier JF \& Noblet J (1999) Effect of growth potential (body weight and breed/castration combination) on the feeding behaviour of individually kept growing pigs. Livestock Production Science 6, 13-22.

Quiniou N, Dubois S \& Noblet J (2000) Voluntary feed intake and feeding behaviour of group-housed growing pigs are affected by ambient temperature and body weight. Livestock Production Science 63, 245-253.

Quiniou N, Noblet J, van Milgen J \& Dubois S (2001) Modelling heat production and energy balance in group-housed growing pigs exposed to cold or hot ambient temperatures. British Journal of Nutrition 85, 97-106.

Rafai $\mathrm{P}$ (1974) Influence of the dry and humid air on the weight gain and food-conversion of fattening pigs. Különlenyomat a Kisérletügyi Közlemények LXVII/B, 41-56.

Rinaldo D \& Le Dividich J (1991a) Assessment of optimal temperature for performance and chemical body composition of growing pigs. Livestock Production Science 29, 61-75.

Rinaldo D \& Le Dividich J (1991b) Effects of warm exposure on adipose tissue and muscle metabolism in growing pigs. Comparative Biochemistry and Physiology 100A, 995-1002.

Stombaugh DP \& Grifo AP Jr (1977) Heat production and respiratory quotient changes with food intake in swine. Transactions of the American Society of Agricultural Engineers 20, 954-960.

Sugahara M, Baker DH, Harmon BG \& Jensen AH (1970) Effect of ambient temperature on performance and carcass development in young swine. Journal of Animal Science 31, 59-62.

Van Milgen J, Bernier JF, Lecozler Y, Dubois S \& Noblet J (1998) Major determinants of fasting heat production and energy cost of activity in growing pigs of different body weight and breed/castration combination. British Journal of Nutrition 79, 509-517.

Van Milgen J, Noblet J, Dubois S \& Bernier JF (1997) Dynamic aspects of oxygen consumption and carbon dioxide production in swine. British Journal of Nutrition 78, 397-410.

Vermorel M, Bouvier J-C, Bonnet Y \& Fauconneau G (1973) Construction et fonctionnement de 2 chambres respiratoires du type circuit ouvert pour jeunes bovins (Construction and operation of two open-circuit respiration chambers for young cattle). Annales de Biologie Animale, Biochimie, Biophysique 13, 659-681.

Xin H \& DeShazer JA (1991) Swine response to constant and modified diurnal cyclic temperatures. Transactions of the American Society of Agricultural Engineers. 34, 2533-2540. 